\title{
Determinants of Corporate Social and Environmental Disclosure on Websites: the Case of Bahrain
}

\author{
Omar Juhmani \\ University of Bahrain, Bahrain \\ *Corresponding Author: ojuhmani@uob.edu.bh
}

Copyright $@ 2014$ Horizon Research Publishing All rights reserved.

\begin{abstract}
The aim of this study is to investigate the level of social and environmental information disclosure practices in websites of companies listed on Bahrain Bourse, also to determine the influence of firm size, profitability, financial leverage, firm age and audit firm size on the level of social and environmental information disclosures under legitimacy theory. To achieve the aims of this study, content analysis and statistical analysis were used. Content analysis by word count is used to determine the level of social and environmental disclosures on websites of Bahraini companies. To determine the factors that explain the level of social and environmental information disclosures, descriptive statistics and multiple regressions analysis were used. The findings indicate that $57.57 \%$ of the sampled listed companies provided social and environmental information in their 2012 annual reports and their websites. Commercial banks and insurance companies made the most disclosure of social and environmental information, while the least disclosure was made by companies in the hotels and tourism sector and industrial sector. Multiple regression analysis revealed that financial leverage and audit firm size had a significant relationship with the level of social and environmental information disclosure.
\end{abstract}

Keywords Social and Environmental, Disclosure, Websites, Factors, Legitimacy Theory, Bahrain Bourse, Bahrain

\section{Introduction}

Social and environmental reporting is commonly referred to as corporate social responsibility reporting (Deegan, 2007). The concept of corporate social and environmental responsibility was first introduced in 1990s by multinational companies, but no attention was given at that time. Environmental disasters and global warming have increased corporate environmentally responsibility awareness. Therefore, many corporations take as much responsibility for environmental issues and reflecting growing social expectations and concerns.

Organizations having the most active role in the market economy, cannot confine their attention to economic goals only, but must focus on a more extended qualitative approach and pay attention to their environmental and social responsibility practices through internal and external reporting (Guthrie and Farneti, 2008). The development of these practices in early and mid 1990s had a trend taking the form of disclosure within annual report. Further, as such reporting practices become widespread and social and environmental disclosures made by some organizations become more extensive to report, companies started to publish it in a separate social and environmental report (Deegan, 2007). As a result, corporate environmental disclosure is increasingly an important issue to corporate investors, public policy makers and the general public. These disclosures are important, because they provide environmental performance information and influence capital markets (Villiers and Staden, 2011). Therefore, corporate investors and other stakeholders need to use environmental information in their decision-making. There is extensive evidence that social and environmental information is useful for decision-making by investors and other stakeholders (Blacconiere and Patten, 1994 and Richardson and Welker, 2001). In response to investors' and other stakeholders' concerns about corporate environmental policies, many firms are voluntarily increasing their level of social and environmental disclosure through different sources and media. However, the most well-known and widely used media are annual reports and websites.

Recently Bahraini companies have reported voluntary social and environmental disclosure in their websites. Bahrain is thus following a universal trend to use the websites as a way to provide direct access to social and environmental information, particularly to existing and potential investors. The practice of corporate reporting on the websites is relatively new in Bahrain. The development of securities market in Bahrain, however, has caused expansion of this practice day by day. Motivated by the growing social and environmental information disclosures, the author performed this study to investigate the level of social and environmental information disclosure practices on websites of companies listed on Bahrain Bourse, also to determine the influence of firm size, profitability, financial leverage, firm age and audit firm size on the level of social and environmental information disclosures under legitimacy theory. 
The remainder of this paper is organized as follows: the next section reviews previous research; section three presents the research hypotheses; the study sample, data and its analysis and research method is provided in section four; while section five analyses and discusses the research results; finally, the conclusion of the study considered briefly in section six.

\section{Literature Review}

A review of literature from Western and Asia-Pacific regions indicate a low level of environmental disclosure practices but there has been a considerable increase in the number of organizations performing environmental accounting and reporting (Gibbon and Joshi, 1999). Haniffa and Cooke (2002) suggest that corporate disclosure practice reflects the underlying environmental influences that affect company accounting practices in different countries. Previous empirical studies have shown that social and environmental information disclosures are varies across companies, industries, and time (Gray et al., 1995, 2001; Hackston and Milne, 1996). Williams et al (1999) used content analysis to investigate corporate social disclosures from four countries: Australia, Singapore, Malaysia, and Hong Kong through annual reports and websites. They found that Australian and Singaporean companies provided more social disclosures on their websites than in annual reports but there were no significant differences in Malaysia and Hong Kong. Villiers and Staden (2011) also used content analysis to compare corporate environmental disclosures on websites and in annual reports of 120 North American firms. They found different levels of environmental disclosures, and companies disclosed more environmental information on their websites when faced with an environmental crisis and more in their annual reports when they had a bad environmental reputation. Ortas et al. (2014) examined the influence of companies' financial factors on the extent of corporate environmental sustainability reporting in an impressive sample of 3931 companies operating in 51 industries and 59 countries. Using a quantile regression they found that, legitimacy theory, agency theory, political costs theory, and signal theory offers a better understanding of the complex structure of the dependencies found among factors such as company size, leverage, return on assets, research and development spending, market return and market capitalization, and commitment to environmental reporting.

In Thailand Kuasirikun and Sherer (2004) examined the annual reports of 63 Thai firms in 1993, and 84 in 1999, they found an increase from $44 \%$ to $45 \%$ in narrative environmental disclosures. Connelly and Limpaphayon (2004) examined a sample of 120 Thai listed companies' annual reports and found a significant positive association between market valuation and disclosures but not between environmental reporting and corporate accounting performance. Ratanajongkol et al. (2006) found that environmental disclosure made by the 40 largest Thai firms in 1997, 1999, and 2001 decreased over the study period. Rahman et al. (2010) found no relationship between environmental disclosure and financial performance of 27 Thai listed companies, but Suttipun and Standton (2011) found a relationship between the amount of disclosure and company size of 75 Thai companies. Suttipun and Stanton (2012) found that 96 percent of the 50 Thai listed companies provided environmental disclosures in their annual reports and 88 percent on websites.

Cormier and Morgan (2004) examined the extent of web-based environmental disclosure as well as its determinants. They found that firm's context with industry, with wide trends and practices playing an important role in explaining both print and web environmental disclosure. Bolivar and Garcia (2004) examined the practices of corporate environmental disclosures of 35 Spanish firms on their web-sites. They found that financial environmental reporting disclosed in the financial statements was quite limited and there was a need to link non-financial environmental reporting and financial reporting to provide users of information with more details of corporate environmental disclosures.

Naser et al. (2006) tested the variation in the level of corporate voluntary social responsibility disclosure, in a sample of 21 Qatari listed companies. They found a wide variations in Corporate social responsibility disclosure, and these variations were associated with firm size and firm leverage. Also in Qatar, AlNaimi et al. (2012) found a low level of corporate social responsibility reporting (whether measured in terms of the number of companies disclosing or in terms of the corporate social responsibility reporting page proportion of the annual report) among Qatari companies.

In Bangladesh Hossain et al. (2006) found on average $8.33 \%$ of Bangladeshi companies disclose social information in their annual reports, and the disclosure levels are associated with the nature of the company, presence of debentures in the corporate annual reports, and the net profit margin. Dutta and Bose (2007) found that web-based corporate reporting in Bangladesh is still infancy, only 38.81 percent of companies have a web, and a wide variation in the level of on-line corporate reporting across 15 sectors has been found. Dutta and Bose (2007) conducted another study in Bangladesh; also found that web-based corporate environmental reporting in Bangladesh is still in it's infancy as the level of environmental disclosures on websites is very low. In Indonesia Setyorini and Ishak (2012) found that corporate social disclosure is associated with return on assets, firm' size, and firm's earning management.

In Malaysia Alarussi et al. (2009) found that level of technology, ethnic of chief executive officer and firm size are significant factors in explaining both Internet financial disclosure and Internet environmental disclosures. Hassan et al. (2012) concluded that public listed companies in Malaysia have undertaken significant effort and have acted proactively in utilizing the Internet as a medium for social responsibility disclosures. This is evident from the fact that only $73 \%$ companies had provided social responsibility information on the Internet.

Akrout and Othman (2013) examined environmental disclosure determinants in Arab Middle Eastern and North 
African (MENA) companies. Using a sample of 153 web sites of listed companies, findings show a negative and significant relationship between environmental disclosure and 'family ownership', the level of environmental disclosure is substantially affected by company size and performance.

In Bahrain there are only three papers examining environmental disclosures. AI-Bastaki (1996) in a study on voluntary social disclosure of 25 listed companies found that none of the companies disclosed information related to environment. Gibbon and Joshi (1999) found that companies are environmentally sensitive, and none of the companies are performing environmental accounting for external purposes, and half of companies prepare environmental reporting for management requirements. Khasharmeh and Desoky (2013) found that only $24.5 \%$ of sampled companies (163 companies listed in the Gulf Cooperation Council (GCC) stock markets) received disclosure scores of 50 percent or more, on average, an industrial company disclosed about $37.0 \%$, while a non-industrial company disclosed about $29.4 \%$.

The contribution of this study is to investigate the level of social and environmental information disclosure practices on websites of all companies listed on Bahrain Bourse which has not been the focus of previous researches. Prior studies AI-Bastaki (1996) investigated the voluntary social disclosure of 25 listed companies on Bahrain Stock Exchange. Gibbon and Joshi (1999) conducted a survey to examine the environmental awareness, disclosure practices and problems associated with environmental accounting and reporting of companies from the industrial sector in Bahrain. Khasharmeh and Desoky (2013) examined Bahrain as one of the GCC member states, and they used a disclosure index to examine the impact of firm characteristics on the level of corporate social responsibility disclosure. While, the current study includes all listed companies on Bahrain Bourse in year 2012, and it examine the level of social and environmental information disclosure by Bahraini companies on websites using content analysis. In addition, the prior studies in Bahrain have been mainly based on agency theory framework, and they often disregarded the influences of legitimacy theory on corporate social and environmental information disclosure. Therefore, in the current study the characteristics of the Bahraini companies that voluntarily disclose social and environmental information on their websites were examined under legitimacy theory.

\section{Legitimacy Theory Framework and Study Hypotheses}

\subsection{Legitimacy Theory Framework}

A number of different theories have been used to explain why corporations might voluntarily disclose social and environmental information to outside parties. According to Gray et al. (1995) the theories that seem to have been most successful in explaining the content and the level of social and environmental information disclosures are the legitimacy theory and the stakeholder theory. Hooghiemstra (2000) stated that, according to legitimacy and stakeholder theories, social and environmental disclosure is used in order to guard corporations' reputation and identity. However, Guthrie and Parker (1990) stated that, legitimacy theory is one of the most adopted theories for explaining corporate social and environmental disclosures. Perrow (1970) defines legitimacy as a generalized perception or assumption that the actions of an entity are desirable, proper, or appropriate within some socially constructed system of norms, value, beliefs, and definitions.

In contrast to agency theory, the legitimacy theory provides a more comprehensive viewpoint on corporate social disclosure as it clearly recognizes that organizations are bound by the social contract in which they agree to perform various socially desired actions in return for approval of their objectives, which will guarantees their continued existence and their successful (Brown and Deegan, 1998; Deegan, 2002; Guthrie and Parker, 1989). Legitimacy theory suggests a relationship between corporate social disclosure and community concerns so that management must react to community expectations and changes. Corporations continually seek to ensure that their activities are perceived by outside parties as legitimate. This is because a corporation is part of a broader social system (Deegan, 2002). Therefore, social disclosure can be viewed as a constructed image or symbolic impression of itself that a firm is conveying to the outside world to control its political or economic position (Neu et al., 1998).

Legitimacy theory research extends to examine the role of the media coverage plays in increasing the public policy pressures faced by companies (Patten, 2002). Deegan (2001) argues that companies are influenced by the society in which they operate. This means that environmental disclosures are considered to constitute a strategy to influence corporate relationships with other parties with which they interact. When there is a change in social expectations, corporations seek to ensure that their activities in terms of human, environmental, and social consequences respond to those changes to meet social expectations. If companies do not operate in a manner consisted with community expectations, they will be penalized. As a result, corporations will adapt their activities to meet community expectations, if they want to be successful.

The most insights into corporate social disclosure derive from the use of legitimacy theory framework which posits that social and environmental disclosure is a way to legitimize a firm's continued existence or operations to the society (Gray et al., 1995). Legitimacy theory has been used by researchers studying social and environmental disclosures, and they indicate that corporations legitimize their activities because corporate management reacts to community expectations (e. g. Patten, 1992, Guthrie and Parker, 1990). Therefore, legitimacy theory assumes that voluntary corporate social and environmental disclosures are in response of social, economic and political factors. Many previous studies on corporate social disclosures have provided evidence that firms do voluntarily disclose 
information in their annual reports as a strategy to manage their legitimacy (e. g. Patten, 1991; Deegan and Rankin, 1996; Woodward et al., 2001).

\subsection{Study Hypotheses}

Based on the legitimacy theoretical framework, five hypotheses and five predictor variables have been developed in the current study. The variables were firm size, profitability, financial leverage, firm age and audit firm size.

\subsubsection{Firm Size}

Large firms in sensitive industries are deemed to be more subjected to public exposure, and often they would face more legitimate issues than smaller firms (Watts and Zimmerman, 1978). Under legitimacy theory, firms' societal existence depends on the acceptance of the society where they operate. Since the firms can be influenced by, and have influences to the society, legitimacy is assumed an important resource determining their survival (Deegan, 2002). The literature suggests that larger firms are more likely to come under public scrutiny and are expected to have more influence on the environment practices of the general business environment. Therefore, large firms with higher societal existence may have taken more legitimacy and may have a higher reputation and involvement of social responsibility than smaller firms.

In the literature, the results regarding the association between firm size and environmental disclosure are mixed. Some studies (e.g., Cormier and Morgan, 2004; Naser et al., 2006; Alarussi et al., 2009; Suttipun and Standton, 2011; Setyorini and Ishak, 2012; Akrout and Othman, 2013) found a positive association, although (Davey, 1982; Ng, 1985; Roberts, 1992; Barako et al. 2006; Smith et al. 2007) did not find such a relationship.

Based on the above discussion and following the legitimacy theory, it's expected that large firms will disclose more social and environmental information than smaller firms. Therefore, the following hypothesis is tested.

H1: There is a positive association between the level of social and environmental information disclosure on websites and Bahraini firm's size.

\subsubsection{Profitability}

The rationale for an influence of profitability on voluntary information disclosure is obvious. Profitable companies have incentives to distinguish themselves from less profitable companies in order to raise capital on the best available terms. One way to do this is through voluntary information disclosure. Deegan, (2002) stated that, legitimacy theory hypothesize that companies are bound to an unwritten social contract within the society where they operate. Failure to comply with their legitimacy will threaten companies' performances and survival. Therefore, more profitable companies can be expected to disclose more voluntary social and environmental information than non-profitable companies. However, the relationship between corporate financial performance and corporate environmental disclosure is arguably one of the most controversial issues yet to be solved (Choi, 1998). The results of different studies measuring the relationship between corporate financial performance and corporate environmental disclosure show mixed results. An association between profitability and social responsibility disclosure has been demonstrated in a number of empirical studies (e g., Smith et al., 2007; Janggu et al., 2007; Akrout and Othman, 2013). However, Cormier and Magnan (2004) documented a weak association between corporate social disclosure and profitability, while (Smith et al., 2007; Connelly and Limpaphayon, 2004; Rahman et al., 2010) found no significant relationship between profitability and corporate social responsibility disclosure. To determine the relationship between profitability and the extent of social and environmental information disclosure on websites, the following hypothesis is tested.

H2: There is a positive association between the level of social and environmental information disclosure on websites and Bahraini firm's profitability.

\subsubsection{Financial Leverage}

Agency theory suggests that the level of financial information disclosure increases as the leverage of the firm grows (Jenses and Meckling, 1976). Some previous studies have found a positive association between leverage and the extent of financial information disclosure (e g., Bradbury, 1992; Malone et al., 1993). Richardson and Welker (2001) argue that social and financial information disclosures have similar determinants, therefore, a similar relationship is expected in the case of environmental disclosure. Guthrie and Parker (1989) stated that, legitimacy theory is based on the notion of a social contract. Dowling and Pfeffer (1975) suggested that an organisation may consider altering the definition of social legitimacy through communication. Therefore, disclosing social and environmental information matches the organization's practices, outputs, goals and values.

Legitimacy theory proposes a relationship between corporate social disclosure and community concerns, so that management must react to community expectations and changes. Roberts (1992) observes that a high degree of dependence on debt would encourage a company to increase social activities and disclose more environmental information in order to meet its creditors' expectations on environmental issues.

According to Christopher and Filipovic (2008) and Ma and Zhao (2009) the higher the leverage, the more the company is likely to disclose social information. Branco and Rodrigues (2008), found out that the relationship between corporate social responsibility disclosure and leverage may be significant in the case of the internet, in which, companies that were highly leveraged did established a closer relationship with their creditors and adopted alternative means to publish their social responsibility disclosure. Therefore, it's expected that, the higher the financial leverage, the more likely the company would disclose social and environmental information. Therefore, the following hypothesis is tested. 
H3: There is a positive association between the level of social and environmental information disclosure on websites and Bahraini firm's financial leverage.

\subsubsection{Firm Age}

Under legitimacy theory, companies' societal existence depends on the acceptance of the society where they operate. Since the companies can be influenced by, and have influences to the society, legitimacy is assumed an important resource determining their survival (Deegan, 2002). Therefore, older companies with longer societal existence may have taken relatively more legitimacy and may have a higher reputation and involvement of social responsibility than younger companies.

As a company operates longer, there will be more communication needed to the outside community. This provides companies with wide social networks, affecting their public images (Yang, 2009). Previous studies support the significant association between age of firm and environmental information disclosure (e. g. Roberts, 1992; Yang, 2009).

Based on the above discussion, it might be expected that the longer a company has been listed on the Stock Exchange, the more likely the company would disclose social and environmental information. Therefore, the following hypothesis is tested.

H4: There is a positive association between the level of social and environmental information disclosure on websites and Bahraini firm's age.

\subsubsection{Audit Firm Size}

It hypothesized that large audit firms are more likely to associate with clients that disclose a high level of information in their annual reports and websites. The assumption here is that, in an attempt to keep their clients, due to the lack of economic power, small audit firms try to meet clients' demands (Malone et al., 1993). Large audit firms are expected to deal with multinational companies conducting their business activities over the world. Therefore, their work is more likely to be influenced by the International Accounting Standards and it is expected that their clients will provide more level of financial and non-financial information in their annual reports and websites.

Previous studies have examined empirically the relation between the characteristics of the audit firm and the level of environmental disclosure and found a positive association between the audit firm size and the level of disclosure. It is believed to be an important responsibility of auditors to recommend their client companies to practice socially responsible accounting practices (Choi, 1998). According to legitimacy theory it clearly recognizes that organizations are bound by the social responsibility in which they agree to perform various socially desired actions in return for approval of their objectives, which will guarantees their continued existence and their successful (Brown and Deegan, 1998; Deegan, 2002; Guthrie and Parker, 1989). Therefore, the following hypothesis is tested to determine the influence of audit firm on the level of social and environmental information disclosure on websites.

H5: Bahraini companies audited by large auditing firms disclose more social and environmental information on websites than those audited by small auditing firms.

\section{Research Methodology}

\subsection{Data and Study Sample}

Due to the relatively small number of companies listed on the Bahrain Bourse all companies were considered for inclusion in the survey. At the end of 2012, there were 48 companies listed on Bahrain Bourse, 44 Bahraini companies and 4 non-Bahraini companies. The 44 Bahraini companies make up the initial sample for this study. However, 5 companies are eliminated from the list of companies because of incomplete data and 6 companies are eliminated because of suspension. Therefore, the final sample consists of 33 Bahraini companies listed on Bahrain Bourse. These companies and their industry classifications are presented in Table 1. The data needed for this study were collected from the websites and annual reports of each company in the study sample.

Table 1. Distribution of Sample Companies

\begin{tabular}{|c|c|c|}
\hline Sector & $\begin{array}{c}\text { Number of } \\
\text { Companies }\end{array}$ & Percentage \\
\hline Commercial Banks & 7 & $21.21 \%$ \\
\hline Investment & 11 & $33.33 \%$ \\
\hline Insurance & 5 & $15.15 \%$ \\
\hline Services & 4 & $12.12 \%$ \\
\hline Hotels and Tourism & 3 & $9.09 \%$ \\
\hline Industrial & 3 & $9.09 \%$ \\
\hline Total & 33 & $100 \%$ \\
\hline
\end{tabular}

\subsection{Websites and the Social and Environmental Information Disclosure}

The survey reveals that all Bahraini companies listed on Bahrain Bourse and included in the study sample have a websites. Company web addresses are collected from the Bahrain Bourse web. The survey and the descriptive statistics revealed a relatively low level of social and environmental information disclosure. The results in Table 2 show that $57.57 \%$ of the sampled companies provided social and environmental information on their websites, also, the results revealed that commercial banks and insurance companies made the most disclosure $100 \%$ and $60 \%$ respectively, while the least disclosure was made by companies in the hotels and tourism sector and industrial sector, both with $33.33 \%$. This result is supported by other previous studies performed in developing countries (e. g., Belal, 2001 in Bangladesh, Naser and Baker, 1999 in Jordan; Savage, 1994 in South Africa; Dutta and Bose, 2007 in 
Bangladesh; AlNaimi et al., 2012 in Qatar; and Khasharmeh and Desoky, 2013 in GCC), which found a low level of corporate social responsibility reporting disclosure.

Table 2. The Percentage of Companies Made Social and Environmental Disclosure

\begin{tabular}{|c|c|c|}
\hline Sector & $\begin{array}{c}\text { Number of } \\
\text { Companies }\end{array}$ & Percentage \\
\hline Commercial Banks & 7 & $100 \%$ \\
\hline Investment & 5 & $65.45 \%$ \\
\hline Insurance & 3 & $50 \%$ \\
\hline Services & 2 & $33.33 \%$ \\
\hline Hotels and Tourism & 1 & $33.33 \%$ \\
\hline Industrial & 1 & $57.57 \%$ \\
\hline Total & 19 & \\
\hline
\end{tabular}

\subsection{Model Development}

To determine the influence of the five firm characteristics on the level of social and environmental disclosure the following multiple regression model is developed and fitted to the data.

$$
\begin{gathered}
\text { Soc Env Dis }=\beta_{0}+\beta_{1} \text { Size }+\beta_{2} \text { Prof }+\beta_{3} \text { Fin Lev }+\beta_{4} \\
\text { Age } \\
+\beta_{5} \text { Aud F Size }+e
\end{gathered}
$$

Where:

Soc Env Dis = Social and environmental information disclosures on the website of each firm;

$$
\begin{aligned}
& \text { Size = firm size; } \\
& \text { Prof = Profitability; } \\
& \text { Fin Lev = Financial Leverage; } \\
& \text { Age = firm age; } \\
& \text { Aud F Size = audit firm size; } \\
& \text { e = error term. }
\end{aligned}
$$

\subsection{The Level of Social and Environmental Disclosure}

The dependent variable in the model is the level of social and environmental information disclosure on websites of Bahraini listed companies. The level of is measured by word count using a checklist divided into 22 different items adopted from previous studies by (Wiseman, 1982; Deegan and Gordon, 1996; Hackston and Milne, 1996; and Suttipun and Stanton, 2012). The checklist as follows:

1) Environmental policy including lists of environmental objectives, environmental issues of concern, and prioritization of environmental issues in term of their impacts;

2) Environmental management systems including ISO14000 and responsible persons;
3) Risk management including environmental impact assessment;

4) Environmental audit;

5) Goals and targets including performance against targets, and actions taken;

6) Compliance with standards including benchmarks;

7) Awards;

8) Input including research and development, energy management, and non- renewable resources used;

9) Processes including technology employed, and capital equipment;

10) Product stewardship including life cycle analysis, and eco-labeling;

11) Wastes consisting of recycling, reduction, and reuse;

12) Land rehabilitation and remediation;

13) Air emissions;

14) Water effluent;

15) Spills;

16) Noise and odors;

17) Environmental spending and activities;

18) Rehabilitation costs consisting of operating costs, provisions, and contingent liabilities;

19) Environmental cost accounting;

20) Sustainable development reporting including a statement that the company subscribes to the principle of sustainable development, details of the principle, attempts to connect the environmental and economic dimensions, impact on the biosphere and habitat carrying capacity, natural trust account, eco-asset sheet, and natural capacity;

21) Education and training; and

22) Litigation about environmental issues.

Table 3. Disclosure Levels (The Average Word Count in Social and Environmental Disclosures)

\begin{tabular}{|c|c|}
\hline Sector & The Average Number of Words on Websites \\
\hline Commercial Banks & 204.71 \\
\hline Investment & 108.72 \\
\hline Insurance & 92.4 \\
\hline Services & 39.5 \\
\hline Hotels and Tourism & 7 \\
\hline Industrial & 28 \\
\hline Total & 101.63 \\
\hline
\end{tabular}

Table 3 shows the disclosure level of social and environmental information, which measured by the average word count. The results revealed that the overall average is 101.63 words, commercial banks recorded the highest average number of words with average of 204.71 words followed by insurance companies with average of 108.72 words, while the least average recorded by companies in the hotels and tourism sector with average of 7 words. The results in Table 3 indicate that there are wide variations in the disclosure practices of social and environmental information 
disclosures of Bahraini listed companies; also, the standard deviations in Table 4 confirm this result.

\subsection{Independent Variables}

This section describes the five independent variables and how they are measured. The independent variables were measured, using data obtained from the 2012 annual reports of Bahraini companies listed on Bahrain Bourse which included in the study sample. The five independent variables are the following:

1) Firm size was measured as the companies' 2012 total of assets.

2) Profitability was measured as the companies' 2012 earnings per share.

3) Financial Leverage was measured as the ratio of the companies' 2012 total liabilities to the companies' 2012 total of shareholders equity.

4) Firm age (the age of the Bahraini companies) were measured in years from the date of incorporation to the end of the 2012 financial year, which for most of the companies was 31 December 2012.

5) Audit firm size was measured as dichotomic variable that can take the value 1 or 0 depending upon it being audited by one of the big international auditing firms or not. If the company is audited by big audit firm will take the value 1 , and 0 if the company is audited by small audit firm.

\section{Results}

Table 4 show the descriptive statistical tests results of dependent and independent variables for the sample of companies. The table presents the minimum, maximum, mean, and standard deviation for all variables in the regression model. According to the descriptive results the extent of social and environmental information disclosure on websites of Bahraini listed companies on average is 101.63 words, and the standard deviations indicate that there are wide variations in the level of social and environmental information disclosure between the listed companies and sectors. This result is supported by other previous empirical studies performed in developing countries (e. g., Naser et al., 2006 in Qatar; and Dutta and Bose, 2007 in Bangladesh), which found a wide variations in the level of corporate social responsibility reporting disclosure between companies and sectors.

Table 5 presents correlations coefficients between all variables. The results show that there is some moderately high correlations between variables, more specifically between firm size (Size) and financial leverage (Fin Lev), and between social and environmental information disclosures (Soc Env Dis) and financial leverage (Fin Lev). However, it has been suggested (Farrar and Glauber, 1967; Judge et al., 1985) that correlation coefficients should not be considered harmful until they exceed 0.80 . Table 6 reveal that the highest correlation is $(0.444)$ between firm size and financial leverage. Therefore, collinearity did not appear to be a serious problem in interpreting the regression results.
Table 4. Descriptive Statistics

\begin{tabular}{|l|r|r|r|r|r|}
\hline & N & Minimum & Maximum & Mean & Std. Deviation \\
\hline Soc Env Dis & 33 & .00 & 472.00 & 101.6364 & 139.73677 \\
Size & 33 & 2724103.00 & $9.22 \mathrm{E} 9$ & $7.7417 \mathrm{E} 8$ & $1.72251 \mathrm{E9}$ \\
Prof & 33 & -.09 & .76 & .2722 & .26360 \\
Fin Lev & 33 & .05 & 7.90 & 1.4580 & 1.88576 \\
Age & 33 & 5.75 & 55.00 & 29.0345 & 13.09105 \\
Aud F Size & 33 & .00 & 1.00 & .7879 & .41515 \\
Valid N & 33 & & & & \\
(listwise) & & & & & \\
\hline
\end{tabular}

Table 5. Correlations Coefficients between Variables

\begin{tabular}{|ll|r|r|r|r|r|r|}
\hline & & Soc Env Dis & \multicolumn{1}{|c|}{ Size } & Prof & Fin Lev & Age & Aud F Size \\
\hline Soc Env Dis Pearson Correlation & 1 & & & & & \\
& Sig. (2-tailed) & & & & & & \\
\hline Size & Pearson Correlation & .018 & 1 & & & & \\
& Sig. (2-tailed) & .919 & & & & & \\
\hline Prof & Pearson Correlation & .141 & -.041 & 1 & & & \\
& Sig. (2-tailed) & .434 & .820 & & & & \\
\hline Fin Lev & Pearson Correlation & $.348^{\circ}$ & $.444^{* *}$ & -.053 & 1 & & \\
& Sig. (2-tailed) & .047 & .010 & .770 & & & \\
\hline Age & Pearson Correlation & .086 & .171 & .114 & .100 & 1 & \\
& Sig. (2-tailed) & .636 & .342 & .528 & .579 & & \\
\hline Aud F Size & Pearson Correlation & .288 & .182 & .256 & -.092 & -.052 & \\
& Sig. (2-tailed) & .104 & .311 & .150 & .609 & .772 & \\
\hline
\end{tabular}

*. Correlation is significant at the 0.05 level (2-tailed). **. Correlation is significant at the 0.01 level (2-tailed).

Table 6. Model Summary

\begin{tabular}{|c|c|c|c|c|}
\hline Model & $\mathrm{R}$ & R Square & $\begin{array}{c}\text { Adjusted R } \\
\text { Square }\end{array}$ & $\begin{array}{c}\text { Std. Error of the } \\
\text { Estimate }\end{array}$ \\
\hline & $.543^{\mathrm{a}}$ & .295 & .164 & 127.76863 \\
\hline
\end{tabular}

a. Predictors: (Constant), Aud F Size, Age, Fin Lev , Prof, Size

Table 7. $A N O V A^{b}$

\begin{tabular}{|c|c|r|r|r|r|}
\hline Model & Sum of & & & \\
& Squares & df & Mean Square & F & Sig. \\
\hline Regression & 184073.389 & 5 & 36814.678 & 2.255 & $.078^{\mathrm{a}}$ \\
Residual & 440770.247 & 27 & 16324.824 & & \\
Total & 624843.636 & 32 & & & \\
\hline
\end{tabular}

a. Predictors: (Constant), Aud F Size, Age, Fin Lev , Prof, Size b. Dependent Variable: Soc Env Dis

The main results of this study are summarized in tables 6 , 7 and 8. The $\mathrm{R}^{2}$ and Adj $\mathrm{R}^{2}$ and F-value for the model are presented in tables 6 and 7. The coefficient of determination $\left(\mathrm{R}^{2}\right)$ under the model was .543 , which indicates that the model is capable of explaining $54.30 \%$ of the variability of the disclosure of social and environmental information in 
the sample Bahraini companies under study. The adjusted $\mathrm{R}^{2}$ indicate that $29.5 \%$ of the variation in the dependent variable in the model is explained by variations in the independent variables. The multiple regression model, reported an $\mathrm{F}$ value of 2.255 for the level of disclosure, which significant at $7.8 \%$ level which indicates that the model is significantly explains the variations in social and environmental information disclosures of Bahraini companies.

Table 8. Multiple Regression, Model Result, Coefficients

\begin{tabular}{|l|r|r|r|r|r|}
\hline Model & \multicolumn{2}{|c|}{$\begin{array}{c}\text { Unstandardized } \\
\text { Coefficients }\end{array}$} & $\begin{array}{r}\text { Standardized } \\
\text { Coefficients }\end{array}$ & & \\
& \multicolumn{1}{|c|}{ B } & Std. Error & \multicolumn{1}{c|}{ Beta } & \multicolumn{1}{c|}{$\mathbf{t}$} & \multicolumn{1}{c|}{ Sig. } \\
\cline { 2 - 3 } & -72.981 & 75.259 & & -.970 & .341 \\
(Constant) & $-2.350 \mathrm{E}-8$ & .000 & -.290 & -1.526 & .139 \\
Size & 24.924 & 90.077 & .047 & .277 & .784 \\
Prof & 37.357 & 13.637 & .504 & 2.739 & .011 \\
Fin Lev & 1.058 & 1.778 & .099 & .595 & .557 \\
Age & 128.004 & 58.969 & .380 & 2.171 & .039 \\
Aud F Size & & & & & \\
\hline
\end{tabular}

a. Dependent Variable: Soc Env Dis

Table 8 presents a summary of the multiple regression results for the social and environmental information disclosure on websites of Bahraini listed companies. Standardized beta coefficients, t-statistics, and probability levels are given for each independent variable in the model. The empirical evidence indicates that there is a highly significant positive association at $1.1 \%$ level between financial leverage (Fin Lev) and disclosure (Soc Env Dis). This result support Hypothesis 3, and suggests that Bahraini listed companies with high financial leverage disclose more social and environmental information on their websites than companies with low financial leverage. This result is consistent with that found in other previous studies (e.g., Naser et al., 2006; Branco and Rodrigues, 2008).

Also this result supports the viewpoint that, a high degree of dependence on debt would encourage a company to increase social activities and disclose more environmental information in order to meet its creditors' expectations on environmental issues (Roberts, 1992). Also this result supports the Branco and Rodrigues (2008) finding that, the relationship between corporate social responsibility disclosure and leverage may be significant in the case of the internet, in which, companies that were highly leveraged did established a closer relationship with their creditors and adopted alternative means to publish their social responsibility disclosure, such as websites.

Moreover, the regression results indicate that there is a highly significant positive association at 3.9\% level between audit firm size (Aud F Size) and disclosure. This result support Hypothesis 5, and suggests that Bahraini listed companies which audited by large audit firms disclose more social and environmental information on their websites than the companies which audited by small audit firms. This result is consistent with that found in other previous empirical studies (e.g., Hossain et al., 2006). Also this result supports the viewpoint that, it is believed to be an important responsibility of auditors to recommend their client companies to practice socially responsible accounting practices (Choi, 1998).

Contrary to the expectations, the findings revealed that, the other independent variables (i. e. firm size; profitability; and firm age) do not appear to be significant in explaining the social and environmental information disclosures on websites of Bahraini listed companies. This finding is consistent with that found in other previous empirical studies (e.g., Smith et al., 2007; Connelly and Limpaphayon, 2004; Rahman et al., 2010) who found no significant relationship between profitability and corporate social responsibility disclosure, and (e.g., Barako et al. 2006; Smith et al. 2007) who did not find a relationship between environmental reporting and firm size.

\section{Conclusions}

The extent of social and environmental disclosures on Bahraini listed companies websites, is measured by word count using a checklist consisting 22 items. To determine the factors that influence the level of social and environmental information disclosures under legitimacy theory, descriptive statistics and multiple regressions analysis were used. The findings indicate that $57.57 \%$ of the sampled listed companies provided social and environmental information on their websites. These disclosures were voluntary in nature and largely qualitative, and the standard deviations indicate that there are wide variations in the level of social and environmental information disclosure between the listed companies and sectors. Commercial banks and insurance companies made the most disclosure of social and environmental information, while the least disclosure was made by companies in the hotels and tourism sector and industrial sector.

Multiple regression analysis revealed that there is a highly significant positive association between financial leverage and disclosure. This result suggests that Bahraini listed companies with high financial leverage disclose more social and environmental information on their websites than companies with low financial leverage. Also, the regression results indicate that there is a highly significant positive association between audit firm size and social and environmental information disclosure. This result suggests that Bahraini listed companies which audited by large audit firms disclose more social and environmental information on their websites than the companies which audited by small audit firms.

The results of this study support the legitimacy theory arguments and supported the notion that, legitimacy theory as an explicator for variability in social and environmental disclosures, and firms do voluntarily disclose information in their annual reports as a strategy to manage their legitimacy. Also, this study provides some empirical evidence related to the level and content of social and environmental disclosure for researchers, students, and academics, and it extends the findings of previous studies in developing countries. 
This study concludes that on the basis of legitimacy theory, the content and the level of social and environmental information disclosed on the Bahraini listed companies' websites is low with wide variations between companies and sectors, and the level of social and environmental disclosure is substantially affected by company financial leverage and audit firm size. The general conclusion of this study is that the social and environmental information disclosures in Bahrain still infancy, and Bahraini companies are not fully utilizing the web for social and environmental communication. In order to improve web-based environmental disclosures the following recommendations have been offered: Bahraini companies should have, on their home page, a hyperlink to a separate page containing social and environmental information; Bahraini companies should disclose both positive and negative social and environmental information; Bahraini companies should disclose both qualitative and quantitative information about their social and environmental activities, not only qualitative information; Bahraini policy makers should play a key role in providing a forward movement to companies to fully utilize the web for social and environmental communication, and to mandate the corporate social and environmental information disclosure in Bahrain.

The main contributions of this study are as follows: this study used electronic media, namely the websites to investigate the content and level of social and environmental information disclosure practices of all companies listed on Bahrain Bourse; this study is the first study in Bahrain which used the content analysis and legitimacy theory to study social and environmental disclosures on websites. Finally, this study contributes to environmental accounting literature, because it provided insight into the social and environmental disclosure practices of listed companies with respect to their operations within developing countries, to make comparisons with similar studies in developed countries.

\section{REFERENCES}

[1] Akrout M. M. and Othman H. B. (2013). A Study of the Determinants of Corporate Environmental Disclosure in MENA Emerging Markets, Journal of Reviews on Global Economics, 2, 46-59.

[2] Alarussi, A. S., M. M. Hanefah, and M. H. Selamat (2009). Internet Financial and environmental Disclosures by Malaysian Companies, Issues in Social and Environmental Accounting, 3(1) , 3-25

[3] Al-Basteki, H. (1996). The Voluntary Adoption of International Accounting Standards by Bahraini Corporations". Advances in International Accounting 8, 47-64.

[4] AlNaimi, H. A., M. Hossain, and M. A. Momin (2012). Corporate social responsibility reporting in Qatar: a descriptive analysis, Social Responsibility Journal, 8(4), 511-526.

[5] Barako, D. G., Hancock, P., and Izan, H. Y. (2006) Relationship between corporate governance attributes and voluntary disclosures in annual reports: The Kenyan experience. Financial Reporting, Regulation and Governance, 5(1), 1-25.

[6] Belal, A.R. (2001). A study of corporate social disclosure in Bangladesh, Managerial Auditing Journal, 16(5), 274-89.

[7] Blacconiere, W. G. and Patten D. M. (1994). Environmental Disclosures, Regulatory Costs and Changes in Firm Value, Journal of Accounting and Economics, 18(3), 357-377.

[8] Bolivar, M and Garcia, B (2004). The corporate environmental disclosures on the Internet: The case of IBEX 35 Spanish, International Journal of Accounting, Auditing and Performance Evaluation, 1(2), 215-266.

[9] Bradbury M. E. (1992). Voluntary disclosure of financial segment data: New Zealand evidence, Accounting Finance, 32(1), 15-26.

[10] Branco, M. C. and Rodrigues, L. L. (2008). Factors influencing social responsibility disclosure by Portuguese companies, Journal of Business Ethics, 83, 685-701.

[11] Brown, N. and Deegan C. (1998). The Public Disclosure of Environmental Performance Information - A Dual Test of Media Agenda Setting Theory and Legitimacy Theory, Accounting and Business Review, 29(1), 21-41.

[12] Connelly, J. T., and Limpaphayom, P. (2004). Environmental reporting and firm performance: evidence from Thailand. The Journal of Corporate Citizenship, 13, 137-149.

[13] Choi, J. S. (1998). An evaluation of the voluntary corporate environmental disclosures: a Korean Evidence, Social and Environmental Accounting, 18(1), 2-7.

[14] Christopher, T., and Filipovic, M. (2008). The extent and determinants of disclosure of Global Reporting Initiative Guidelines: Australian evidence, The Journal of Contemporary Issue in Business and Government, 14(2), 17-40.

[15] Cormier, D and Morgan, M (2004). The impact of the Web on information and communication modes: The case of corporate environmental disclosure, International Journal of Technology Management, 27(4), 393-416.

[16] Davey, H. B. (1982). Corporate Social Responsibility Disclosure in New Zealand: An Empirical Investigation. Unpublished Working Paper, Massey University, Palmerston North, New Zealand.

[17] Deegan, C. and Rankin M. (1996). Do Australian Companies Report Environmental News Objectively? An Analysis of Environmental Disclosures by Firms Prosecuted Successfully by the Environmental Protection Authority, Accounting, Auditing and Accountability Journal 9(2), 50-67.

[18] Deegan, C. (2001). Financial Accounting Theory. Roseville, NSW, McGraw-Hill Book Company Australia Pty Limited.

[19] Deegan, C (2002). Introduction: the legitimizing effect of social and environmental disclosures - a theoretical foundation. Accounting, auditing and Accountability Journal, 15(3), 282-311.

[20] Deegan, C. M. (2007). Financial Accounting Theory (2nd ed.). Australia: McGraw-Hill.

[21] Deegan, C. and Gordon, B. (1996). A study of the environmental disclosure practices of Australian corporations, Accounting of Management Review, 20, 65-91.

[22] Dowling, J., and Pfeffer, J. (1975). Organizational legitimacy: 
social values and organisational behaviour. Pacific Sociological Review, 18(1), 122-136.

[23] Dutta, P and S. Bose (2007). Corporate Social and Environmental Reporting on Corporate Websites: A Study on Listed Companies of Bangladesh, The Cost and Management, 35(4), 31-49.

[24] Dutta, P and S. Bose (2007). Web-based Corporate Reporting in Bangladesh: An Exploratory Study, The Cost and Management, 35(6), 29-45.

[25] Farrar, D. and Glauber, R. (1967). Multicollinearity in Regression Analysis: A Problem Revisited, Review of Economics and Statistics, 49, 92-107.

[26] Gibbon, J. and Joshi P. L. (1999). A Survey of Environmental Accounting and Reporting in Bahrain, Journal of Applied Accounting Research, 4-36.

[27] Gray, R., Javad, M., Power D. M. and Sinclair C. D. (2001). Social and Environmental Disclosure and Corporate Characteristics: A Research Note and Extension, Journal of Business Finance and Accounting, 28(3/4), 327-356.

[28] Gray, R, Kouhy, R, and Lavers, S (1995). Corporate Social and Environmental Reporting: A Review of the Literature and a Longitudinal Study of UK Disclosure. Accounting, Auditing and Accountability Journal, 8(2), 47-77.

[29] Gray, R., Owen, D., and Adams, C. (1996). Accounting and Accountability: Changes and Challenges in Corporate and Social Reporting. London, Prentice Hall.

[30] Guthrie, J., and Farneti, F. (2008). GRI sustainability reporting by Australian public sector organisations. Public Money and Management, 28(6), 361-366.

[31] Guthrie, J. and Parker L. (1989). Corporate Social Reporting: A Rebuttal of Legitimacy Theory, Accounting and Business Review, 19(3), 343-352.

[32] Guthrie, J., and Parker, L. (1990). Corporate social disclosure practice: a comparative international analysis. Advances in Public Interest Accounting, 3, 159-176.

[33] Hackston, D. and Milne M. J. (1996). Some Determinants of Social and Environmental Disclosures in New

[34] Zealand Companies, Accounting, Auditing and Accountability Journal, 9(1), 77-108.

[35] Hackston, D. and Milne M. J. (1996). Some Determinants of Social and Environmental Disclosures in New Zealand Companies, Accounting, Auditing and Accountability Journal, 9(1), 77-108.

[36] Haniffa, R.M. and Cooke, T. E. (2002). Culture, corporate governance and disclosure in Malaysian corporations, Abacus, 38(3), 317-349.

[37] Hassan, N. H., H. Yusoff, and N. Yatim (1012), Disclosing Social Responsibilty Information Via The Internet: A Study On Companies In Malaysia, International Journal of Arts and Commerce, 1(5), 83-96.

[38] Hooghiemstra, R. (2000). Corporate Communication and Impression Management: New Perspectives Why Companies Engage in Corporate Social Reporting, Journal of Business Ethics, 27(1/2), 55-68.

[39] Hossain, M. A., Islam, K. S. and Andrew, J. (2006). Corporate Social and Environmental Disclosure in Developing Countries: Evidence from Bangladesh, Proceedings of the Asian Pacific Conference on International
Accounting Issues, Hawaii, October.

[40] Janggu, T, Joseph, C. and Madi, N. (2007). The current state of corporate social responsibility among industrial companies in Malaysia. Social Responsibility Journal, 3(3), 9-18.

[41] Jensen, M. C. and W. H. Meckling (1976). Theory of the firm: Managerial behaviour,Agency Costs and Ownership Structure, Journal of Financial Economics, 3, 305-360.

[42] Judge, G. G., Griffiths, W. E., Hill, R. C. Lutkepohl, H. and Lee, T. (1985), The Theory and Practice of Econometrics, 2nd ed. (New York: John Wiley and Sons).

[43] Khasharmeh , H. A. and Desoky , A. M. (2013). On-line Corporate Social Responsibility Disclosures: The Case of the Gulf Cooperation Council (GCC) Countries, Global Review of Accounting and Finance, 4(2), 39-64.

[44] Kuasirikun, N., and Sherer, M. (2004). Corporate social accounting disclosure in Thailand. Accounting, Auditing and Accountability Journal, 17, 629-660.

[45] Ma, L. F., and Zhao, Y. (2009). Corporate social disclosure and determinates analysis in listed companies in China. Security Market Guide, 3, 3-9.

[46] Malone, D., C. Fries and T. Jones (1993). An Empirical Investigation of the Extent of Corporate Financial Disclosure in the Oil and Gas Industry, Journal of Accounting, Auditing and Finance, 8, 249-273

[47] Naser, A. and Baker, N.A. (1999), “Empirical evidence on corporate social responsibility reporting and accountability in developing countries: the case of Jordan', Advances in International Accounting, 12, 193-226.

[48] Naser, K., Al-Hussaini, A., Al-Kwari, D. and Nuseibeh, R. (2006). Determinants of corporate social disclosure in developing countries: the case of Qatar, Advances in International Accounting, 19, 1-23.

[49] Ng, L. W. (1985). Social Responsibility Disclosures of Selected New Zealand Companies for 1981, 1982 and 1983. Occasional Paper, 54. Massey University, Palmerston North, New Zealand.

[50] Neu, D., Warsame H. and Pedwell K. (1998). Managing Public Impressions: Environmental Disclosures in Annual Reports, Accounting, Organizations and Society 23(3), 265-282.

[51] Ortas, E., Gallego-Alvarez, I., and Álvarez Etxeberria, I.(2014). Financial Factors Influencing the Quality of Corporate Social Responsibility and Environmental Management Disclosure: a Quantile Regression Approach. Corporate Social Responsibility and Environmental Management, DOI: 10.1002/csr.1351

[52] Patten, D.M. (1991). 'Exposure, Legitimacy and Social Disclosure', Journal of Accounting and Public Policy, 10(4), 297-308.

[53] Patten, D.M. (1992). Intra-industry Environmental Disclosures in Response to the Alaskan Oil Spill: A Note on Legitimacy Theory, Accounting, Organizations and Society, $17,471-475$.

[54] Patten, D. M. (2002). Media Exposure, Public Policy Pressure, and Environmental Disclosure: An Examination of the Impact of Tri Data Availability, Accounting Forum, 26(2), 152-171.

[55] Perrow, C. (1970). Organizational Analysis: A Sociological View (Wadsworth, Belmont, CA). 
[56] Rahman, S. A., Yusoff, R. B., and Mohamed, W. N. (2010) Environmental disclosures and financial performance: an empirical study of Malaysia, Thailand, and Singapore. Social and Environmental Accountability Journal, 29(2), 46-58.

[57] Ratanajongkol, S., Davey, H., and Low, M. (2006). Corporate social reporting in Thailand, the news is all good and increasing. Qualitative Research in Accounting and Management, 3, 67-83.

[58] Richardson A. J., and Welker M. (2001). Social disclosure, financial disclosure and the cost of equity capital, Accounting, Organizations and Society, 26(7), 597-616.

[59] Roberts, W. (1992). Determinants of Corporate Social Responsibility Disclosure an application of Stakeholder Theory, Accounting Organizations and Society, 17(6), 595-612.

[60] Savage, A. A. (1994). Corporate social disclosure practices in South Africa: a research note, Social and Environmental Accounting, 14(1), 2-4.

[61] Setyorini , C. T. and Z. Ishak, (2012). Corporate Social and Environmental Disclosure: A Positive Accounting Theory View Point, International Journal of Business and Social Science, 3(9), 152-164

[62] Smith, M, Yahya, K and Amiruddin, AM (2007). Environmental disclosure and performance reporting in Malaysia, Asian Review of Accounting, 15(2),185-199.

[63] Suttipun, M., and Stanton, P. (2011). Determinates of environmental reporting in corporate annual reports of the Stock Exchange of Thailand (SET). International Journal of Accounting and Financial Reporting, 2(1), 99-115.

[64] Suttipun M. and P. Stanton, (2012). The Differences in Corporate Environmental Disclosures on Websites and in Annual Reports: A Case Study of Companies Listed in Thailand International Journal of Business and Management, 7 (14), 18-31.

[65] Villiers, C. D., and Van Staden, C. J. (2011). Where firms choose to disclose voluntary environmental information. Journal of Accounting and Public Policy, 30(6), 504-525.

[66] Watts, R. L., and Zimmerman, J. L. (1986). Positive accounting theory. London: Prentice-Hall.

[67] Williams, S. M. (1999). Voluntary environmental and social accounting disclosure practice in the Asia-Pacific region: an international empirical test of political economy theory. The International Journal of Accounting, 34(2), 209-238.

[68] Wiseman, J. (1982). An evaluation of environmental disclosures made in corporate annual reports. Accounting, Organizations and Society, 4, 123-133.

[69] Woodward, D., Edwards P. and Birkin F. (2001). Some Evidence on Executives' Views of Corporate Social Responsibility, British Accounting Review 33(3), 357-397.

[70] Yang, C. F. (2009). Empirical study on the influential factors of social responsibility of Chinese enterprises, The Economists, 69-79. 